\title{
AUTORREPRESENTAÇÃO INDÍGENA EM AS FABULOSAS FÁBULAS DE IAUARETÊ, DE JECUPÉ
}

\author{
Célia Regina Delácio Fernandes* \\ Enilze de Souza Breguedo**
}

RESUMO: Este artigo apresenta um estudo sobre a narrativa As fabulosas fábulas de Iauaretê (2007) do autor indígena Kaká Werá Jecupé, presente nas obras complementares do Programa Nacional do Livro e do Material Didático (PNLD) de 2010, e tem por objetivo analisar como os indígenas se autorrepresentam nessa obra, considerando a contribuição da literatura infantojuvenil para evidenciar as culturas desses povos no ambiente escolar. A seleção dessa obra considerou primordialmente as narrativas que retratam as culturas indígenas sob o olhar do próprio indígena. O recorte fundamenta-se pela necessidade de abordar a história e a cultura indígena no ambiente escolar, porque desde a promulgação da Lei $n^{\circ} 11.645$, de 10 de março de 2008, torna-se obrigatório trabalhar essa temática em sala de aula. Assim, por estar presente em todas as escolas públicas brasileiras, essa obra precisa ser divulgada e estudada para que não se perpetuem estereótipos e preconceitos. Nessa perspectiva, propõe-se uma pesquisa inspirada nos estudos decoloniais e pós-coloniais, que buscam refletir em uma nova maneira de visualizar os povos indígenas através da literatura infantojuvenil de autoria indígena. Portanto, para auxiliar na construção epistemológica dessa investigação utilizou fontes literárias que dialogam com questões referentes a autoria indígena e sua representação na literatura brasileira infantojuvenil, tais como os desenvolvidos por Lajolo e Zilberman (1985), Wapichana (2018), Bonin (2012), Jekupé (2009) e Thiél (2012).

ABSTRACT: This article presents a study about the narrative The fabulous fables of Iauarete (2007) by the indigenous author Kaká Werá Jecupé, present in the complementary works of the Programa Nacional do Livro e do Material Didático (PNLD) of 2010, and aims to analyze how the indigenous people represent themselves in this work, considering the contribution of children's literature to highlight the cultures of these peoples in the school contexto. The selection of this work considered primarily the narratives that portray the indigenous cultures under the eye of the indigenous himself. The cutout is based on the need to approach indigenous history and culture in the school context, because since the promulgation of Law $n^{o}$. 11.645, March 10, 2008, it has become mandatory to work on this theme in the classroom. Thus, because it is present in all Brazilian public schools, this work needs to be disseminated and studied so that stereotypes and prejudices are not perpetuated. From this perspective, a research inspired by decolonial and post-colonial studies is proposed, which seek to reflect on a new way of viewing indigenous peoples through children's literature of indigenous authorship. Therefore, to assist in the epistemological construction of this investigation, it used literary sources that dialogue with issues related to indigenous authorship and its representation in Brazilian children's literature, such as those developed by Lajolo and Zilberman (1985), Wapichana (2018), Bonin (2012), Jekupé (2009) and Thiél (2012).

PALAVRAS-CHAVE: Literatura infantojuvenil; Escritores indígenas; Literatura indígena.

KEYWORDS: Children's and youth literature; Indigenous writers; Indigenous literature. 


\section{INTRODUÇÃO}

Escrever sobre a literatura indígena é uma proposta de reflexão sobre o outro e o diferente na sociedade, tendo em vista que os povos indígenas pertencem a culturas diferentes da estabelecida no mundo não indígena. Desse modo, deslumbramos fomentar um pensamento movido pelos estudos decoloniais e pós-coloniais, que opera no processo de descontruir a imagem posta pelos colonizadores aos povos indígenas, ou seja, uma visão generalizada e uniformizada, em que são representados como seres sem civilizações, sem culturas, incapazes, selvagens, preguiçosos e traiçoeiros. Partindo desse escopo, este artigo objetiva analisar como os indígenas são autorrepresentados nas obras de autoria indígena, considerando a contribuição da literatura infantojuvenil para evidenciar as culturas desses povos.

Nessa perspectiva, selecionamos a obra As fabulosas fábulas de Iauaretê (2007), do indígena Kaká Werá Jecupé, presente nas obras complementares do Programa Nacional do Livro e do Material Didático (PNLD) de 2010, destinada ao público do Ensino Fundamental. Uma vez que trabalhar com obras literárias indígenas permite a construção de um repertório calcado em valores e visões diferentes das narradas a partir de outras concepções de tempo e espaço como, por exemplo, as construídas pelos romancistas indianistas, que utilizavam como fontes inspiradoras o modo sintético de representar os povos indígenas. Com efeito, Thiél (2012, p. 21-22) coloca que alguns escritores brasileiros, como Gonçalves Dias, José de Alencar, e norte-americanos, como Washington Irving e James Fenimore Cooper, criaram na literatura personagens indígenas como o "bom selvagem", para refletir ideias nacionalistas, idealizar a natureza e criticar a civilização.

Desse modo, sob a proposta de visualizar o "novo indianismo" literário do século XXI, que narra uma literatura diferente da escrita pelos povos não indígenas, compreendemos a necessidade de estudar a história indígena construída pelo próprio indígena. Haja vista que, após a promulgação da Lei n. ${ }^{\circ} 11.645$, de 10 de março de 2008, a qual estabelece a obrigatoriedade de estudar a história e a cultura indígena no ambiente escolar, o professor precisaria incluir essa temática nos conteúdos programáticos. Assim, atrelado à Lei, que surgiu em resposta a várias mobilizações políticas e sociais, em defesa dos direitos indígenas, o Governo Federal se viu obrigado a incluir no PNLD, por meio da seleção e compra de acervos, obras que abordam diversos aspectos históricos e culturais dos povos indígenas.

Para compreendermos a dimensão histórica da autoria indígena nas compras governamentais do século XXI, observamos que as obras de literatura para jovens leitores, no geral, surgiram no Brasil apenas no século XIX e, consequentemente, a literatura de temática indígena só se tornou "visível" há poucas décadas, posto que no seu 
início apresentava-se na perspectiva subalterna do homem não indígena, uma vez que ele estava "sempre do lado errado, a não ser quando se civiliza, convertendo-se ao cristianismo e aliando-se aos brancos". (ZILBERMAN; LAJOLO, 1986, p. 131).

Nas últimas décadas, no entanto, esse cenário vem se modificando e é possível verificamos o grande número de obras com títulos que falam de povos indígenas. Como expõe Bonin (2009), são obras escritas a partir de vários olhares e ênfases variadas. São produções literárias que discutem representações de personagens diferentes, saindo dos padrões estabelecidos pela literatura europeia, ou seja, são universos narrativos em que o escritor indígena decide o que deve ser narrado.

Dessa maneira, esta pesquisa é de suma importância para o avanço dos estudos nessa área, pois promove um olhar mais cauteloso sobre as obras literárias escrita por autores indígenas, isso porque a narrativa aqui analisada nos oportuniza perceber os povos originários como capazes de produzir textos com valores estéticos e literários. Este trabalho também é relevante para a sociedade, uma vez que o acesso a literatura indígena nos ajuda a romper estereótipos, promover o respeito à diversidade, reconhecer e valorizar a contribuição de diferentes etnias que constitui a identidade brasileira.

Nesse sentido, procuramos mostrar que a literatura de autoria indígena, além de expressar o pertencimento étnico, passa a questionar a representação indígena realizada na literatura ocidental brasileira. Para tanto, organizamos este artigo em duas partes: a primeira referese a uma discussão introdutória sobre a trajetória da literatura infantojuvenil, apontando a inserção de autores indígenas nesse gênero literário; a segunda, por sua vez, trata-se da análise da narrativa As fabulosas fábulas de Iauaretê, do autor indígena Kaká Werá Jecupé, enfatizando o modo como este representa seus povos em sua narrativa.

\section{A PRESENÇA DE ESCRITORES INDÍGENAS NA LITERATURA INFANTOJUVENIL}

Ler uma obra literária destinada ao público infantil e juvenil não era algo comum como podemos verificar na atualidade. Ela foi construída historicamente, seu início ocorreu na França, no século XVII, durante o reinado de Luís XIV, o Rei Sol, que manifesta abertamente a sua preocupação com uma literatura para crianças e jovens. Tudo isso levou o francês Jean de La Fontaine a escrever uma coletânea de fábula para as crianças da corte e para o filho de Luís XIV, o pequeno Luís de França, então com seis anos de idade. A descoberta dessa literatura, no século XVII, tomou forma no mundo europeu e as primeiras publicações surgiram:

[...] foram escritas histórias que vieram a ser englobadas como literatura também apropriada à infância: as Fábulas, de La Fontaine, editadas entre 1668 e 1694, As aventuras de Telêmaco, de Fénelon, lançadas postumamente, em 1717, e os Contos da mamãe Gansa, cujo título original era Histórias ou 
narrativas do tempo passado com moralidades, que Charles Perrault publicou em 1697. (LAJOLO; ZILBERMAN, 1985, p. 15).

Para Lajolo e Zilberman, esses três escritores foram os responsáveis pela entrada dos primeiros textos literários para o público infantil no Ocidente. Mas foi o escritor francês Charles Perrault o responsável pelo primeiro surto da Literatura para o público não adulto. Os Contos da mamãe Gansa foi sua primeira obra, uma coletânea de contos de fadas, recolhida das histórias populares de tradição oral.

No Brasil observamos que as obras de literatura infantil e juvenil só surgiram no início do século XX, porém, são adaptações e traduções dos clássicos infantis europeus. A produção literária para esse público só se configura nos anos de 1920, quando Monteiro Lobato publica Narizinho Arrebitado.

No entanto, só na década de 1990, segundo Zilberman (2005, p. 48), que temos o que se convencionou chamar de boom da literatura infantojuvenil em que a produção cultural destinada às crianças e jovens se expande. Foi um momento em que o mercado editorial percebe que esse público se torna consumidor potencial de obras literárias, e investe em livros que dialogam com esse leitor. Com isso, lançam obras no mercado catalogadas como infantojuvenis e, consequentemente, escritores começam a publicar livros que atraiam o interesse desse leitor em formação.

Concomitante a consolidação do gênero, suas narrativas ganham novas tendências temáticas, pautam em assuntos sociais. A morte, o divórcio, a diversidade, a sexualidade, os problemas sociais, entre outros, passam a ter presença na literatura infantojuvenil. Não obstante, questões e representações dos indígenas tornam-se presente na literatura infantojuvenil.

Porém, em seu início, no século XIX e também em sua trajetória até o final do século XX, os indígenas eram apresentados nas narrativas sob o olhar dos autores não indígenas. Consistiam em obras indigenistas, produzidas a partir de uma expectativa ocidental, em que ignoravam os elementos que compõe a cosmovisão e a textualidade indígena, salientavam apenas características negativas. De fato, a literatura infantojuvenil, manteve um estilo tradicional, com reflexo do romantismo, em que focava na construção de uma literatura nacional, onde o indígena era traçado como o "bom selvagem" que vivia em comunhão com a natureza e até com o colonizador.

Então, com o passar dos anos, a literatura infantojuvenil torna-se mais comprometida com o outro e, por isso, na década de 1990, o indígena torna protagonista e narrador da sua própria história. Mas alterar esse lugar de fala, na literatura, não foi algo democrático e súbito, correspondeu a profundas mudanças políticas na sociedade brasileira. Os movimentos sociais, pedagógicos, políticos e intelectuais gerados nas últimas décadas viabilizaram leis de inclusão dos cidadãos indígenas na sociedade. 
Nesse aspecto, convém relembrarmos dos movimentos indígenas, ocorridos na década de 1970, em defesa de seu protagonismo, mobilizando-os por meio de grupos organizados na defesa dos seus direitos. Os primeiros passos para o surgimento dos movimentos indígenas ainda foram dados na década de 1960, mas, segundo a antropóloga Manuela Carneiro da Cunha (2012), a organização das assembleias efetivamente ocorreu no início de 1970, em 1974, quando o Conselho Indigenista Missionário (CIMI), órgão ligado à Conferência Nacional dos Bispos do Brasil (CNBB), passou a assessorar as assembleias indígenas. As assembleias reuniram líderes indígenas de diferentes comunidades do país, do Norte ao Sul.

Desde então, deixou para trás "o estatuto da relativa incapacidade", inscrito no Código Civil de 1916, Lei $\mathrm{n}^{\mathrm{o}} 3.071$, de $1^{\circ}$ de janeiro de 1916, que dava ao Estado o poder sobre os povos indígenas e a Lei $\mathrm{n}^{\circ} 6.001$, de 19 de dezembro de 1973, que, mesmo dispondo sobre o Estatuto do Índio, não deixou de seguir os mesmos princípios do Código Civil, em que o indígena é considerado relativamente incapaz e deveria ser tutelado por um órgão indigenista estatal (o Serviço de Proteção ao Índio - SPI; atualmente, a Fundação Nacional do Índio - FUNAI) até que eles estivessem integrados à sociedade brasileira.

Nesse processo de garantia de direitos dos indígenas, nos meados da década de 1970, segundo a autora Troquez (2012), houve intensa mobilização no campo indigenista brasileiro que envolveu agentes indígenas (caciques, professores, agentes de saúde) e não indígenas, em favor da garantia de direitos dos indígenas, entre eles o direito à diferença. Fazia parte das reivindicações do movimento a proposição e efetivação de processos de escolaridade diferenciados para os indígenas. Com isso, surge a "Educação Escolar Indígena (EEI), que constitui no processo de escolaridade diferenciada para os povos indígenas" (TROQUEZ, 2012, p. 15).

Consequentemente, com a EEI foram implantadas escolas nas comunidades indígenas de maneira que, cada etnia tem direito a uma escola específica, na área indígena onde reside, com ensino em sua própria língua, material didático específico, com professores da própria etnia com formação em cursos específicos. Sobre a implantação das escolas indígenas, Jekupé (2009) diz que sempre almejou ter escolas nas aldeias, porque só assim surgirão os escritores indígenas.

A mobilização de indígenas e não indígenas em prol da garantia de direitos dos indígenas, culminou com as prerrogativas da Constituição Federal Brasileira de 1988, Lei ${ }^{\circ} 7.689$, de 15 de dezembro de 1988, que inaugura um novo tempo para as ações relativas aos povos indígenas, rompe com a tradição secular, de um indígena incapaz, e a ele é reconhecido o direito de manter a sua própria cultura. E, portanto, fixa uma nova era entre os povos indígenas e o Estado brasileiro.

Após a aprovação da Constituição Federal, na década de 1990, com o novo cenário brasileiro, os indígenas começaram a frequentar as escolas, ter diplomas universitários, a 
fazer cursos técnicos, a realizar cursos de formação profissional e a sociedade brasileira passa a olhá-los um pouco mais diferenciado.

Em razão disso, em 1996, o Governo Federal estabelece as Diretrizes e Bases da Educação Nacional (LDBEN), Lei no 9.394, de 20 de dezembro de 1996. Em seus artigos 78 e 79, objetivam que a União, em colaboração com entidades de fomento à cultura e de assistência aos indígenas, desenvolverá programas integrados de ensino e pesquisa, para a oferta de educação escolar bilíngue e intercultural aos povos indígenas.

Por consequência a LDBEN (9.394/96) foi modificada pela Lei ${ }^{\circ} 10.639$, de 9 de janeiro de 2003, que tornou obrigatório o ensino da história e cultura afro-brasileira no ensino fundamental e médio. Porém, a lei não abordava o indígena e, desde modo, em 2008, a Lei $\mathrm{n}^{\circ} 10.639$ foi alterada pela Lei $\mathrm{n}^{\circ} 11.645$, de 10 março de 2008, na qual modifica o artigo 26-A da LDBEN, incluindo o estudo da história e cultura afro-brasileira e indígena em todo o currículo escolar, nos estabelecimentos de ensino fundamental e de ensino médio, especificamente nas disciplinas de História, Artes e Literatura.

Dentro desta realidade, a tarefa das instituições de ensino foi incluir nos currículos escolares conteúdos relacionados às minorias, como o estudo da história e da cultura indígena. A escola, por sua vez, é um lugar propício de promoção de saberes e atitudes sociais, assim cabe a ela proporcionar informações e possibilitar meios de compreensão e valorização do indígena. As autoras Mancini e Troquez (2009) explicam com mais clareza:

Entendemos que pensar a temática indígena na Educação é abrir caminho para o reconhecimento das diferenças culturais existentes em nossa sociedade, em nosso entorno. É abrir caminho também para o respeito a estas diferenças é, sobretudo, um compromisso ético com 'o mundo presente' - nossa realidade local, regional e nacional. (MANCINI; TROQUEZ, 2009, p. 183).

Por compreender que a literatura pode fornecer uma verdadeira mudança de olhar em relação aos povos indígenas, que os programas governamentais de incentivo à leitura, como o Programa Nacional Biblioteca da Escola (PNBE) e o Programa Nacional do Livro Didático e do Material Didático (PNLD), incluíram nos acervos literários, embora em número insignificante, obras literárias indígenas, executadas por indígenas, e obras literárias não indígenas, mas com personagens e temáticas indígenas.

Em consequência dos fatos, surge um conjunto das produções literárias infantojuvenis realizadas por sujeitos indígenas. Atualmente temos umas dezenas deles, são autores pertencentes a várias etnias (mundurukus, pataxós, guaranis, xavantes, terenas, potiguaras, ticunas, entre outras). O escritor indígena Wapichana (2018) coloca que embora não consegue ter um número preciso de autores indígenas, ele acredita que tem cerca de cinquenta que publicam por editoras, pois existem aqueles que publicam dentro 
das comunidades, junto à prefeitura, à Secretaria de Educação, com o Governo Federal, ONGs, por isso não tem ideia de quantos autores têm. De acordo com autor, a produção da literatura indígena

surgiu timidamente, não oficialmente, em 1998, com a publicação da narrativa A terra de mil povos: história indígena brasileira contada por um índio, escrito por Kaká Werá Jecupé. Antes disso, na década de 1980, Eliane Potiguara escrevia um jornalzinho que tinha algo sobre texto, ou alguma coisa nesse sentido. (WAPICHANA, 2018, p. 75)

Para o autor, esse foi o surgimento oficial, no sentido mais amplo, da literatura indígena para a sociedade brasileira, pois a publicação de Kaká Werá rendeu uma matéria no programa "Fantástico" e foi tomada como um evento extraordinário, por ser um escrito indígena.

Assim, despido do exotismo que desde o século XVIII revestia a imagem do indígena na literatura, os povos originários que protagonizam a literatura infantojuvenil contemporânea são diferentes, são escritores indígenas que vivem nas aldeias e alguns nas cidades, mas fruto de uma educação indígena. Essas produções escritas pelos próprios indígenas, Jekupé (2009) chamou de literatura indígena, e também de literatura nativa, termo inicialmente defendido por ele. Com efeito, o indígena relata que por muito tempo algo o deixava angustiado: o fato de não achar livros escritos por indígenas. Ele comenta como seus parentes são grandes contadores de histórias, logo teriam grandes escritores: "isso seria muito importante porque a sociedade ia conhecer a cultura, mas escrita pelo próprio povo" (JEKUPÉ, 2009, p. 11). É uma escrita que, segundo Thiél (2012), segue os meios e códigos que lhe são peculiares, podendo expressar uma voz individual ou coletiva.

\footnotetext{
Eles afirmam, em diferentes momentos, a relevância de se escutar a voz indígena, destacam o valor de suas tradições, a atualidade de seus saberes apostando, possivelmente, numa outra sensibilidade a ser desenvolvida nas gerações de pequenos leitores, para quem as obras de literatura infantil são endereçadas. $\mathrm{E}$ as formas de estabelecer a diferença indígena (aquilo que distinguiria cada povo e que os diferenciaria da sociedade majoritária) também são variáveis. (BONIN, 2012, p. 43).
}

A literatura indígena é, em consequência, instrumento político aliado aos movimentos indígenas, sobretudo do movimento dos professores indígenas nas escolas diferenciadas, como base para conceder a esses povos o protagonismo social, cultural, epistemológico e político. Nesse sentido, na literatura indígena, os autores procuram informar sobre a situação do indígena no século XXI. Essas obras investem em uma caracterização mais específica, como aspectos referentes a identidade indígena, de forma a desmistificar o que 
muitos acreditam, de que os indígenas devem permanecer do mesmo jeito de centenas de anos atrás. "Nesta direção, uma "nova história" sobre os povos indígenas começa a ser escrita. Esta perspectiva histórica específica busca recuperar a visão temporal em que o índio não é mais visto como um ser "parado no tempo" ou sem historicidade". (MANCINI; TROQUEZ, 2009, p. 188).

Na perspectiva apresentada, até os anos de 1980 não se conhecia autores indígenas, com livros publicados, mas atualmente esse cenário está muito diferente, porque o número de obras publicadas e de escritores indígenas vem crescendo visivelmente. São narrativas que estão atreladas a própria história de vida. Seja ela, individual, coletiva, escrita ou oral, narrar para o indígena é exercer poder.

\begin{abstract}
Sendo assim, acredito que nossas comunidades têm que lutar para que haja escolas em suas aldeias, porque o futuro da defesa de nosso povo está na educação. É através do conhecimento que teremos líderes fortes e preparados. O dominante usa dessa arma para nos enfrentar, para nos humilhar. Se temos que enfrenta-los, por que não usar dessa mesma arma? Uma arma que não precisa de guerra; só de conversa, discurso. (JEKUPÉ, 2009, p. 16).
\end{abstract}

As palavras do autor indígena afirmam que a literatura indígena é indispensável para a defesa da cidadania, bem como retira das mãos dos não indígenas o poder exercido historicamente. Então, ler suas obras promove reflexões sobre a presença dos indígenas na história brasileira e proporciona abertura para outras tradições literárias construídas por meio de um discurso multimodal. Esse é o caso da narrativa As fabulosas fábulas de Iauaretê, como veremos a seguir, em que Kaká Werá Jecupé permite ao leitor conhecer suas matrizes culturais, que fazem parte da história do nosso país e, desse modo, valoriza a identidade cultural dos indígenas.

\title{
2 AUTORREPRESENTAÇÃO DO SUJEITO INDÍGENA NA LITERATURA INDÍGENA
}

Enquanto a narrativa de autoria não indígena insiste em reproduzir a visão eurocêntrica dos povos originários, a narrativa de Kaká Werá Jecupé (Kaká Werá) autorrepresenta o sujeito indígena e sua coletividade. As fabulosas fábulas de Iauaretê, além de autoria do texto verbal ser indígena, é ilustrada também por uma indígena, Sawara, a filha do autor, que tinha 11 anos de idade quando a obra foi publicada, em 2007, pela editora Peirópolis.

Carlos Alberto dos Santos é seu nome de batismo cristão, segundo o Jecupé (2018) Kaká é um apelido, um escudo. De acordo com suas tradições, uma palavra pode proteger ou destruir uma pessoa; o poder de uma palavra na boca é o mesmo de uma flecha no arco, de modo que às vezes usam apelidos como patuás. Já, Werá Jecupé é o seu tom, ou seja, seu espírito nomeado. 
Conforme as informações do próprio Jecupé (2007), ele é filho de pais de um subgrupo dos antigos tapuias ou da etnia txucarramães de origem caetité, nasceu em $1^{\circ}$ de fevereiro de 1964, em São Paulo. De tradição nômade, seus pais deixaram a região do Araguaia e migraram para Minas Gerais e, posteriormente, uniram-se aos guaranis da região que deslocavam para São Paulo. Embora indígena, o autor só teve contato com a cultura de suas origens, quando na juventude, década de 1980, passou a conviver com os guaranis de São Paulo, cidade na qual viveu durante 12 anos. De acordo com as informações contidas na obra, sobre os dados biográficos do autor, além de escritor ele é ambientalista, conferencista, fundador do Instituto Arapoty, organização voltada para a difusão dos valores sagrados e éticos da cultura indígena e desde 1998, leciona na Fundação Peirópolis e na Unipaz (Universidade da paz).

Marcado pelo hibridismo étnico, sua trajetória de vida é realizar trabalhos que promovam o respeito e a diversidade cultural dos povos indígenas. Nessa configuração, Kaká Werá Jecupé publica seis obras, duas para o público adulto e quatro para o infantojuvenil, que visam trazer para o leitor saberes ancestrais, não só de uma, mas de várias etnias indígenas. Isto posto, para o público infantojuvenil, além da narrativa em análise, o autor publicou Oré Awe Roiru'A Ma: todas as vezes que dissemos adeus (1994), A Terra dos Mil Povos: história indígena brasileira contada por um índio (1998), e Tupã Tenondé: a criação do Universo, da Terra e do Homem, segundo a tradição oral Guaraní (2001). São obras consideradas "Altamente Recomendáveis" pela Fundação Nacional do Livro Infantil e Juvenil (FNLIJ) e que marcam presença constante em programas de incentivo à leitura, promovidos por diversos órgãos governamentais, como: Tupã Tenondé, selecionada para o Programa Livro Aberto da Biblioteca Nacional, em 2007, e para o Cantinho de leitura da Secretaria da Educação de Goiás, em 2005; A Terra dos Mil Povos: história indígena brasileira contada por um índio, selecionada para o PNLD, em 1999 e 2001, e para o Programa Fome de Livros, em 2004; As fabulosas fábulas de Iauaretê, selecionada para o Programa Livro Aberto da Biblioteca Nacional, em 2007, para o catálogo de Bologna, em 2008, para o Programa Mais Cultura da Biblioteca Nacional 2008, e PNLD 2010.

Com a trajetória temática que se propõe em seus textos literários, o livro As fabulosas fábulas de Iauaretê, de Kaká Werá Jecupé, aborda a cultura ouvida dos povos de língua tupi-guarani (via tradição oral), por meio das "fabulosas fábulas" (via tradição escrita ocidental). Destinada ao público infantojuvenil, o livro é um reconto a partir de outros recontos. $\mathrm{O}$ ato de contar histórias, como já mencionado, remonta às sociedades tradicionais, as quais desconheciam a escrita e que recorriam à tradição oral. Assim, Kaká Werá Jecupé construiu sua obra através de um projeto de recontos, como explica no prefácio:

Desde quando minha filha Sawara tinha 5 ou 6 anos eu conto estas histórias para ela. Nesse projeto, lhe pedi que me recontasse [...] aquilo que ela 
lembrasse e gostasse, para me ajudar na escritura. [...] Depois, selecionamos as aventuras que mais nos divertiram e também aquelas que nos emocionaram. (JECUPÉ, 2007, p. 7).

A partir dessa fala do autor, é possível percebermos que ele não abandonou o jeito dos indígenas de zelar pelas tradições de seus povos, ele utilizou da oralidade, recurso ancorado entre seus membros mais velhos, que funcionam como guardiões da memória e da tradição, para, a partir dela, aproximar o leitor desse imaginário e descobrir a complexidade da riqueza dessas culturas ainda desconhecidas ou silenciadas.

A obra de Kaká Werá é composta por dezoito episódios, incluído prefácio e posfácio, os quais vão se entrelaçando uns aos outros, que podem ser lidos independentes ou não, alguns deles já conhecidos na literatura infantojuvenil. Recontados a partir das histórias coletadas pelo próprio autor ouvindo os Kamaiurá, Trumai e Xavantes no Parque Nacional do Xingu e também entre narradores Krahô, na beira do Rio Tocantins. Outras são reescritas de narrativas elaboradas pelo general Couto de Magalhães em seu livro $O$ selvagem, publicado em 1874. Segundo os dados do posfácio de Kaká Werá Jecupé (2007, p. 82-85), a obra do general foi construída a mando do imperador Dom Pedro II, que tinha o objetivo de criar um curso de tupi com base em mitos e histórias populares dos povos nativos. Assim, o folclorista viajou, em 1873, de norte a sul do país para pesquisar e recolher lendas, contos e fábulas dos povos indígenas kadiweus, bororos, mundurukus e tupis.

As histórias transcritas por Kaká Werá Jecupé, do livro $O$ selvagem, são, em especial, aquelas em que aparecem os episódios de Iauaretê com o jabuti, a raposa e a anta. Foram narrativas deixadas pelo general na língua Tupi, e adaptadas pelo autor, com elementos de sua própria experiência de vida.

Quadro 1: Versões dos episódios do livro $O$ selvagem

\begin{tabular}{|l|l|l|}
\hline Obras & As fabulosas fábulas de Iauaretê & \multicolumn{1}{|c|}{ O selvagem } \\
\hline \multirow{5}{*}{ Episódios } & Iauaretê e o jabuti & $\begin{array}{l}\text { O jabuti e outra onça (Iauaraeté } \\
\text { câuéra cereme mi) }\end{array}$ \\
\cline { 2 - 3 } & Iauaretê e a anta & $\begin{array}{l}\text { O veado e a onça (Cuaçú } \\
\text { Iauaraeté) }\end{array}$ \\
\cline { 2 - 3 } & Iauaretê, a raposa e o jabuti & $\begin{array}{l}\text { A raposa e a onça (Micura } \\
\text { Iauaraeté) }\end{array}$ \\
\hline
\end{tabular}

Fonte: O autor (2020).

Na passagem do livro do general para o livro de Kaká Werá, as histórias sofreram pouquíssimas interferências locais. Mesmo com seu jeito próprio de contar, o autor manteve nas aventuras a tradição que o precedeu. No episódio Iauaretê e a anta, por 
exemplo, ainda que houve troca de personagens, ele seguiu à risca o gênero literário deixado por Couto de Magalhães.

A obra inicia com a capa, num contraste entre o verbal e o visual marcado por uma linha horizontal, dividindo esses dois universos de escrita, de maneira a dar ao leitor uma sinopse do que vai encontrar na narrativa. Muito colorida, como no universo indígena, ela adquire a capacidade de despertar o interesse do leitor, principalmente o infantil. Nessa perspectiva, os desenhos e o título funcionam como um rótulo sobre o que existe na obra, de modo a causar uma grande expectativa, pois sinalizam que o leitor mergulhará no fantástico mundo das aventuras de Iauaretê.

Os personagens principais são a Iauaretê e seus filhos, Juruá e Iauaretê-mirim. Iauaretê é uma onça-rei, que gosta de aventuras e desventuras, mas devido a uma magia de Tupã, de dia é onça-pintada e à noite vira homem.

Um dia, Iauaretê se transforma em guerreiro Kamaiurá, se apaixona e casa com Kamakuã, a indígena mais bela da aldeia, gerando dois filhos, Juruá e Iauaretê-mirim. Juruá tornouse caçador, zombador e rancoroso, que destruiu a natureza e foi castigado por Anhangá (espírito protetor da floresta), a mando de Tupã. Arrependido, Tupã concedeu a ele o direito de recomeçar e, assim, "foi iniciar a criação de outra tribo, outra aldeia, que muitas e muitas luas depois se tornaria uma enorme cidade". (JECUPÉ, 2007, p. 50).

Iauaretê-mirim, por sua vez, tornou-se um excelente canoeiro, mas trazia um grande conflito na alma: às vezes, em sua solidão, sentia algumas coisas estranhas, como pular no pescoço de alguém, quando em contato com as pessoas. Todavia, sentia grande paz nos momentos em que estava só entre os bichos, sentimentos esses, de pajé, que são "todos aqueles que têm uma onça raivosa e uma onça pacífica no coração" (JECUPÉ, 2007, p. 56), então, perseguiu o pássaro Acauã para conseguir a pena mágica e voar até Jacy-Tatá, a mulher-estrela, senhora do segredo dos poderes dos pajés, e torná-lo pajé.

Desse modo, as histórias desses personagens vão se concatenando numa narrativa que traz diversos personagens, como o pajé, papagaio, Anhangá, Jacy-tatá, Kamakuã, jabuti, Tupã, anta, ratinho, coruja, pirarucu, boto, lobo-guará, e outros, que, embora sejam secundários, são fundamentais para o desenvolvimento da trama. Neles, segundo Colombres (2005, p. 39), há uma oposição do logos da razão ocidental, visto que o autor desobedece à epistêmica do "bem contra mal", "divino versus humano", "homem versus animal", entre outras, levando o leitor a refletir sobre o sentido da história, que vai transformando o indígena, de objeto da imagem, em sujeito do discurso. Portanto, na narrativa indígena o recurso comunicacional é o mítico, que encanta e dá direcionamento segundo a sua própria espiritualidade, como os seres da floresta, não levando a cabo os valores literários apresentados nas narrativas ocidentais, que exaltam os heróis europeus (branco). 
Há também personagens da natureza, como o jatobá e o rio, que dialogam com o guerreiro a ponto de ajudá-lo nas passagens difíceis da sua transformação de Iauaretê-mirim a Pajé:

\begin{abstract}
Como era uma dessas manhãs de ouro e prata com que a Mãe do dia presenteia de vez em quando nossos olhos, e estava quente, Iauaretê foi até à beira do rio beber água e começou a observar nas águas a sua imagem. Ficou olhando, olhando, olhando. Enquanto as águas corriam bem suavemente cantando uma canção ancestral, a imagem mudava de criança para menino e de menino para homem e de homem para velho e de velho para um tom dourado de prata, e assim ia circulando entre o silêncio e o som dos hábitos das manhãs, mudando, mudando, mudando. - O que está acontecendo, Mãe Cobra Grande? O que você quer me dizer? — Eu nada, somente canto. (JECUPÉ, 2007, p. 62).
\end{abstract}

Nesse diálogo, entre o herói da narrativa e o rio (Cobra-grande), eles se comunicam de forma metafórica, uma espécie de linguagem cifrada, que mantêm preservados os segredos da tradição cultural dos povos indígenas. Segundo Munduruku (2005), são seres que metem medo nas crianças, mas que também embalam a fantasia.

Assim, na voz de um narrador observador, o autor recria a partir da mitologia zoológica da família de língua tupi-guarani, o mito da onça-rei Iauaretê, num conjunto de fábulas. Ele parte de ideia de que o conhecimento da realidade passa mais por uma ordem simbólica do que por uma ordem fenomênica.

Mas, há uma questão a ser considerada em relação ao gênero textual da obra, mesmo os textos serem considerados fábulas na perspectiva teórica ocidental, visto que segundo Coelho (2000, p. 165), "são formas simples de 'criação espontânea', [...] de situações vividas por animais que alude a situação humana e tem por objetivo transmitir moralidade", Kaká Werá não as reconhecem como tal. Isso porque, nas sociedades indígenas, como explica Munduruku (2005) na apresentação do seu livro Contos indígenas brasileiros, tais narrativas têm sentido cosmogônico, de verdade e seus personagens não são criação de uma mente insana, mas de uma realidade repleta de mistérios. Nesse contexto, o mito, para os indígenas, constitui um elemento explicativo da ordem social e, como tal, verdadeiro.

Acreditamos que mesmo intitulando sua obra como fábulas, por seguir uma classificação ocidental, o autor deixa claro que o título não faz referência ao gênero da narrativa. Isso é passível de ser observado no momento em que ao ler, no prefácio, que as histórias são saboreadas como as "ditas fábulas" e, além disso, ele apresenta a palavra fábula entre "aspas", o que parece indicar divergência com essa tipologia. Porém, como a fábula está vinculada à tradição oral, modalidade discursiva dos indígenas, a mesma pode constituir um mito, o que demonstra a flexibilidade das fronteiras entre os gêneros que compõem a textualidade indígena. 
O mito de Iauaretê se funda na própria identidade de Kaká Werá, isso porque, no discurso do narrador, sugere ao leitor (comunidade externa ao território geopolítico indígena) sua cultura, história, códigos simbólicos e míticos da sua etnia indígena. Essa abordagem se observa em toda extensão do livro, posto que o autor se identifica com o personagem de sua obra.

Nesse sentido, a vinda para a área urbana, a condição de diáspora, é destacada por Kaká Werá na figura de Juruá que, após sair de sua aldeia, foi viver com os não indígenas.

\begin{abstract}
Você vai voltar a ser gente, mas não vai morar na aldeia do seu irmão, aquela dos homens que se pintam de vermelho e fazem desenhos de onça no corpo de vez em quando. Você vai morar lá no alto, do outro lado do rio, e vai morar na aldeia dos que se pintam de branco. Lá, com sua inteligência e com seu dinamismo, você poderá fazer muitas coisas boas e ajudar aquele povo crescer. (JECUPÉ, 2007, p. 50).
\end{abstract}

Notamos que o indígena, ao frequentar ou residir nos territórios dos não indígenas, além da oportunidade de usufruir dos recursos daquela civilização, também (e principalmente) poderá ensinar muito para aquele povo, substancialmente no que concerne ao amor e cuidado pela natureza, uma vez que, para os povos indígenas, o homem é integrado à natureza.

Embora nessa condição de dispersão dos povos indígenas gotejada pelo personagem, não deixa, mesmo não estando no local enunciado, de referenciar o pertencimento a esse território, ou seja, por meio da memória partilhada, o autor reconhece-se nas raízes de seu povo. Nas palavras de Hakiy (2008, p.38): "Ai está o papel da literatura indígena, produzida por escritores indígenas, que nasceram dentro da tradição oral, que podem não viver mais em aldeias, mas que carregam em seu cerne criador um vasto sentido de pertencimento". Esta identificação com a obra irá se evidenciar quando o narrador tece uma teia discursiva em conformidade com os lugares culturais de cada sujeito enunciativo.

Essa retirada dos indígenas de seus territórios tradicionais é retratada no episódio "O buraco da onça", quando a onça cai numa armadilha e fica atemorizada em sentir que, a qualquer momento, poderá ser capturada e morta por um caçador. Trata-se de uma história em que, logo de início, o narrador leva ao leitor uma reflexão sobre as ações dos homens não indígenas, além de fazer pensar sobre o destino da onça, felino que está sendo extinto do planeta.

Mesmo vivendo em território urbano, Kaká Werá não deixou de incorporar em sua vida elementos das culturas ancestrais. Na frase inaugural "não sei se vocês sabem, mas nas aldeias indígenas costuma-se fazer festas e celebrações para honrar os animais, na aldeia Kamaiurá [...], toda lua cheia se faz uma grande festa para a onça”, (JECUPÉ, 2007, p. 
24), do episódio "A mulher que se casou com Iauaretê", o narrador indica a "nós" um costume dos povos indígenas. Essa passagem leva a entender que, ao escrever uma obra, contando seus costumes, o escritor indígena reconstrói sua identidade, de forma a tomar posse de sua cultura.

Ainda no contexto de reconstrução identitária, o trecho "ele foi caçar e ela foi fazer biju com farinha de mandioca" (JECUPÉ, 2007, p. 27), o narrador mostra a presença das tradições indígenas. Nas comunidades indígenas, cada povo tem seus próprios costumes e modos de vida. A divisão de tarefas, por exemplo, marca essa tradição, ou seja, em algumas comunidades eram (e ainda são) as mulheres que preparam os alimentos, fazem artefatos e outras atividades internas, enquanto os homens cuidam da parte externa, como guerrear, caçar e cuidar da segurança das aldeias.

Os resultados observados no discurso literário de Kaká Werá mostram aspectos da sua cultura, e dá indícios de que a identidade indígena é recriada segundo seus valores cognitivos, éticos e políticos, contrapondo com a cultura hegemônica. Esses recursos de criação literária correspondem ao herói criado pelo autor, que muitas vezes passa por situações de dúvida, inquietação, erros e acertos, e, por fim, se transforma em um "outro" herói, um outro sujeito. Como forma sutil de propor uma reflexão sobre a diferença:

\footnotetext{
- Preciso muito de ajuda! Eu não sei direito o que eu sou. Às vezes sinto vontade de pular no pescoço de alguém. Às vezes sinto que sou a própria paz. Acho que ser filho de gente onça é muito ruim. Ajuda-me! Por favor! Eu já não sei o que eu sou! Se gente ou bicho...

- Meu jovem guerreiro, você é como um pajé! Todos nós temos uma onça raivosa e uma pacífica no coração. Vamos ser sempre aquela a que o nosso pensamento oferecer alimento. (JECUPÉ, 2007, p. 56).
}

Como vemos, o herói criado por Kaká Werá propõe uma contundente reflexão sobre a diferença. Demonstra, por meio do discurso literário, que a autorrepresentação indígena pode e deve ser ressignificada, de modo a desconstruir o discurso inventado pelo homem não indígena de que o indígena é "bárbaro, de cultura primitiva, irracional e selvagem" e de que o não indígena é "civilizado e superior".

Assim, mesmo fazendo uso da escrita, ferramenta do sistema "civilizacional" do branco ocidental, a narrativa permite ao leitor, indígena ou não, a adentrar na zona de contato com os Guaranis. Isso só foi possível com os movimentos sociais e com as políticas públicas que inseriram no século XXI diferentes grupos culturais no bojo da literatura brasileira.

Desse modo, em As fabulosas fábulas de Iauaretê, ao mesmo tempo que traz muita diversão ao leitor indígena e não indígena, principalmente às crianças, pois foi construída sob uma perspectiva infantil, como a presença da fauna e da flora, que por si só já encanta 
o público infantil, ela explica o "ser índio" de uma forma poética, descrevendo em suas histórias os mitos e as crenças que permeiam a cultura indígena dos povos guaranis.

Embora seja um livro voltado para o público infantil e juvenil, a obra retrata as vivências e aspectos de um homem adulto, tentando estabelecer uma ponte entre as duas culturas das quais faz parte, ao mesmo tempo que recompõe o patrimônio cultural das comunidades guaranis. Esse patrimônio cultural, transmitido de geração em geração, foi recriado na obra por meio das experiências vividas pelo grupo étnico ali representado, como a interação com a natureza e sua história, que fornece um sentimento de identidade e cultura.

\section{CONSIDERAÇÕES FINAIS}

A literatura indígena é vista pelos indígenas como grande arma para a defesa de seus povos. Por meio dela, eles podem mostrar seus problemas (terras roubadas, rios destruídos, indígenas assassinados, indígenas estupradas e tantas outras coisas), como também suas concepções de mundo (cosmologias, crenças e ritos), ou seja, narra as histórias da luta dos povos indígenas para manter suas identidades.

Nesse contexto, procuramos analisar e discutir em que medida a obra As fabulosas fábulas de Iauaretê, do indígena Kaká Werá Jacupé, presente nos acervos complementares do PNLD de 2010, contribui para evidenciar as identidades culturais dos povos indígenas.

Nesse sentido, em As fabulosas fábulas de Iauaretê (2007), Kaká Werá Jecupé utiliza de situações arquetípicas sagradas, onde o mundo abunda em mistérios e também os animais e a natureza da floresta dialogam com o herói, para aproximar o leitor indígena ou não das complexas riquezas culturais do povo guarani, ainda desconhecidas ou silenciadas na cultura brasileira. É como explica Jecupé (2007, s.p.): “o jeito 'índio' de contar, o jeito fantástico que ele ouviu e aprendeu". Dessa maneira, a tradição de contar histórias oralmente fica enriquecida pela escrita do autor e os saberes adquiridos com a vivência e reinvenção da experiência ampliam a possibilidade de compreensão dos povos guaranis.

Com efeito, foi possível constatarmos na obra analisada que o autor se autorrepresenta, por meio de suas referências culturais, crenças, costumes, cotidiano de sua aldeia, bem como desconstrói a representação dos não indígenas, ao recontar, também, que não são canibais, ingênuos, preguiçosos e desculturados. Portanto, no texto, o indígena é, ao mesmo tempo, narrador e protagonista de sua própria história, razão pela qual é uma narrativa que mostra as identidades étnicas dos povos guaranis, descrevendo aspectos próprios de suas tradições, seus costumes e seus conhecimentos ancestrais, que são amplamente conhecidas pelos mais velhos dessas comunidades.

Destarte, é uma produção literária para indígenas e não indígenas, pois, nela, a criança ou adolescente indígena pode se identificar e ao não indígena são apresentadas culturas 
diferentes das suas. Desse modo, contribui para romper preconceitos e estereótipos acerca dos indígenas, uma vez que, por muito tempo, o "índio" foi representado ora como um selvagem, agressivo e ignorante, incapaz de conviver com a "civilização superior"; ora como pacífico, porém, sujeito ingênuo, quase infantil e desprovido de inteligência. $\mathrm{Na}$ perspectiva indígena, As fabulosas fábulas de Iauaretê permitem demonstrar que os indígenas souberam se apropriar das tecnologias contemporâneas, como publicar livros, sem, contudo, perder sua ancestralidade, suas raízes culturais, suas crenças. Isso porque, explicitamente, a obra retrata a cultura e o cotidiano indígena, permitindo uma visibilidade positiva da identidade e da cultura desses povos e, de forma implícita, revela a familiaridade de Kaká Werá em se comunicar através da escrita ocidental, assim como seu significativo conhecimento literário.

\section{REFERÊNCIAS}

BONIN, Iara Tatiana. Literatura infantil de autoria indígena: diálogos, mesclas, deslocamentos. Currículo sem Fronteiras, v. 12, n.1, 2012, p. 36-51.

Cenas da vida indígena na Literatura que chega às escolas. Campo Grande/MS: Série-Estudos - Periódico do Mestrado em Educação da UCDB. n. 27, jan./jun. 2009, p. 97-109.

BRANDÃO, Ana Lúcia. A literatura infantil dos anos 80. In: SERRA, Elizabeth D'Angelo (Org.). 30 anos de literatura para crianças e jovens: algumas leituras. Campinas, SP: Mercado de Letras: Associação de Leitura do Brasil, 1998. p. 47-58.

BRASIL. Lei $\mathbf{n}^{\circ}$ 11.645, de 10 março de 2008. Altera a Lei $n^{\circ} 9.394$, de 20 de dezembro de 1996, modificada pela Lei $\mathrm{n}^{\circ} 10.639$, de 9 de janeiro de 2003. Disponível em: <http://www.planalto.gov.br/ccivil_03/_Ato2007-2010/2008/Lei/L11645.htm>. Acesso em: 16 mar. 2020.

COELHO, Nelly Novaes. Literatura Infantil: teoria, análise, didática. São Paulo: Moderna, 2000.

CUNHA, Manuela Carneiro da. Índios no Brasil: história, direitos e cidadania. São Paulo: Claro Enigma, 2012.

HAKIY, Tiago. Literatura indígena: a voz da ancestralidade. In: Literatura Indígena Brasileira Contemporânea: criação, crítica e recepção. Julie Dorrico, Leno Francisco Danner, Heloisa Helena Siqueira Correia e Fernando Danner (Orgs.). Porto Alegre, RS: Editora Fi, 2018.

JECUPÉ, Kaká Werá. As fabulosas fábulas de Iauaretê. Ilustrações de Sawara. São Paulo: Peiropolis, 2007.

JEKUPÉ, Olívio. Literatura escrita pelos povos indígenas. São Paulo: Scortecci, 2009. 
LAJOLO, Marisa; ZILBERMAN, Regina. Literatura infantil brasileira: história \& histórias. São Paulo: Ática, 1985.

MANCINI, Ana Paula Gomes; TROQUEZ, Marta Coelho Castro Desconstruindo estereótipos: apontamentos em prol de uma prática educativa comprometida eticamente com a temática indígena. Campo Grande: UCDB, Revista Tellus, ano 9, n. 16, p. 181208, jan./jun. 2009. Disponível em: <www.tellus.ucdb.br/projetos/tellus/index.php/tellus/article/download/185/212 > .

Acesso em: 23 jan. 2018

MUNDURUKU, Daniel. Literatura Indígena e as novas tecnologias da memória. Leetra Indígena: Revista do Laboratório de Linguagens LEETRA, São Carlos, v. 1, n. 1, p. 1623, 2012.

Contos indígenas brasileiros. 2 ed. São Paulo: Global, 2005.

PUCCI, Magda; ALMEIDA, Berenice. Cantos da floresta: iniciação ao universo musical indígena. São Paulo: Peirópolis, 2017.

THIÉL, Janice Cristine. Pele silenciosa, pele sonora: a literatura indígena em destaque. Belo Horizonte: Autêntica, 2012.

TROQUEZ, Marta Coelho Castro. Documentos curriculares para a educação escolar indígena: da prescrição às possibilidades da diferenciação. Tese (doutorado). Campo Grande, MS, 2012.

WAPICHANA, Cristino. Por que escrevo? - relato de um escritor indígena. In: DORRICO, Julie; DANNER, Leno Francisco; CORREIA, Heloisa Helena Siqueira; DANNER, Fernando (Orgs.). Literatura indígena brasileira contemporânea: Criação, crítica e recepção. - Porto Alegre, RS, Editora Fi, 2018. p. 75-79.

ZILBERMAN, Regina; LAJOLO, Marisa. Um Brasil para crianças - para conhecer a literatura infantil brasileira: histórias, autores e textos. São Paulo: Global, 1986.

ZILBERMAN, Regina. Como e por que ler a literatura infantil brasileira. Rio de Janeiro: Objetiva, 2005.

\footnotetext{
* Professora Doutora, do Programa de Pós-graduação Mestrado em Letras da Faculdade de Comunicação, Artes e Letras, da Universidade Federal da Grande Dourados - UFGD.

** Mestre em Letras, do Programa de Pós-graduação Mestrado em Letras da Faculdade de Comunicação, Artes e Letras, da Universidade Federal da Grande Dourados - UFGD.
} 